\title{
リン酸-水ーメチル $n$-プロピルケトン系の液液平街*
}

\author{
諸 戸 定 正 ${ }^{* *} \cdot$ 渡 边 昭**

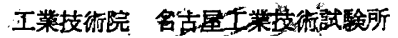

\begin{abstract}
藉霉
リン酸-水一有機溶媒系の液液平衡は，あまり調べられ ていないようである1,3)。リン酸-水ーメチル $n$-プロビル ケトン系についても，その液液平衡データは文献中に見

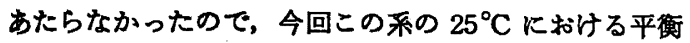
を測定した。
\end{abstract}

\section{1. 溶解度曲楾}

試 料：リン酸は試薬特級品をそのまま使用した。 メチル $n$ ープロピルケトンは特級品を無水炭酸カリウム で脱水後精留したものである。3 成分組成の計算は，リ

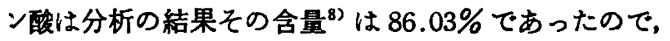
残りの $13.97 \%$ はすへて水分として計算した。メチル クープロピルケトンの純度は100\%とみなした。

装着と方法：、ン酸-水ーメチル $n$-プロ ピルケトン 系の溶解度は白濁法"とよって求めた。

容量 $100 \mathrm{ml}$ のガラス製共栓付き 3 角フラスコ中に重 豐既知の 2 成分（リン酸とメチル $\boldsymbol{n}$-ブロピルケトンま を泩水）を入れ, $25.0^{\circ} \mathrm{C}$ の佰温水槽中でらりまぜた後， 約 1 時間静置した。これにビューレットより他の 1 成分 （水またはメチル クーブロピルケトン）を徐々に滴下し， この滴下成分を加えるたびに激しくしんとらして液が白 濁する点を求めた。Table 1 がその結果である。

\section{2. 对応楾}

対応線決定のために用いた装置および方法は既報5,6) のものと同じである。3 成分のいろいろな割合の混合溶 液をふりまぜた後, $25.0^{\circ} \mathrm{C}$ の佰温水槽中に $2 \sim 3$ 時間浸 清した。この間約 30 分ごとに激しくふりまぜた後，約 1 時間静直した。分離した両相内のリン酸の浱度はメチ

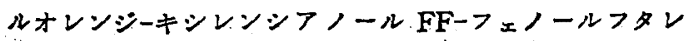
インの混合指示薬を用いて標準水酸化ナトリウムによる

* <Liquid-Liquid Equilibria of the System Phosphoric Acid-Water-Methyl n-Propyl Ketone>

Received on June 6, 1973

* Sadamasa Moroto (正会员) and Akira Watanabe（正会员） Gov. Ind. Research Inst., Nagoya, Nagoya, Japan
中和滴定法 ${ }^{7,8)}$ て求めた。ぞの値を Table 2 に示す。溶 解度曲線と対応線は Fig. 1 のよ5に表される。この困 で,プレイトポイント近くの対応線は若千省略してあ る。

分配曲線は Fig. 2 のよらになる。

\section{3. テータの相䦛}

Fig. 3 は Othmer-Tobias のプロット9を行った図で ある。屈折点を有する直線関係が成立する。

\begin{tabular}{|c|c|c|}
\hline \multicolumn{3}{|c|}{$\begin{array}{r}\text { Table } 1 \text { Solubilities -in ternary systems phosphoric } \\
\text { acid-water-methyl } n \text {-propyl ketone }\left(25^{\circ} \mathrm{C}\right)\end{array}$} \\
\hline $\begin{array}{c}\text { Methyl n-propyl ketone } \\
{[\text { wt } \%]}\end{array}$ & $\begin{array}{l}\text { Phosphoric acid } \\
\text { [wt \%] }\end{array}$ & $\begin{array}{l}\text { Water } \\
{[w t \%]}\end{array}$ \\
\hline 96.37 & 0 & 3.63 \\
\hline 91.58 & 4.01 & 4.41 \\
\hline 85.97 & 7.82 & 6.21 \\
\hline 72.55 & 16.37 & 11.08 \\
\hline 64.56 & $21: 66$ & 13.78 \\
\hline 57.15 & 25.58 & 17.27 \\
\hline 39.05 & 35.11 & 25.84 \\
\hline 29.42 & 39.56 & 31.02 \\
\hline 23.42 & 42.14 & 34.44 \\
\hline 12.97 & 46.48 & 40.55 \\
\hline 6.78 & 48.42 & 44.80 \\
\hline 5.55 & 45.28 & 49.17 \\
\hline 4.61 & 42.03 & 53.36 \\
\hline 4.56 & 0 & 95.44 \\
\hline 4.48 & 6.44 & 89.08 \\
\hline 4.26 & 14.28 & 81.46 \\
\hline 4.10 & 37.63 & 58.27 \\
\hline 3.88 & 31.97 & 64.15 \\
\hline 3.83 & 24.45 & 71.72 \\
\hline
\end{tabular}

Table 2 Tie-line data at $25^{\circ} \mathrm{C}$

\begin{tabular}{|c|c|c|c|c|c|c|}
\hline \multirow{2}{*}{ Run No: } & \multicolumn{3}{|c|}{ Organic layer } & \multicolumn{3}{|c|}{ Water layer } \\
\hline & $y_{A} *$ & $y_{B} * * *$ & $y o^{* *}$ & $x_{A}^{*}$ & $x_{B}{ }^{* *}$ & $x_{c}^{* * *}$ \\
\hline 1 & 0.18 & 3.6 & 96.2 & 18.17 & 77.5 & 4.3 \\
\hline 2 & 0.34 & 3.6 & 96.1 & 24.55 & 71.1 & 4.3 \\
\hline 3 & 1.80 & 4.0 & 94.2 & 37.62 & 58.1 & 4.3 \\
\hline 4 & 2.83 & 4.1 & 93.1 & 39.64 & 56.1 & 4.3 \\
\hline 5 & 4.91 & 5.0 & 90.1 & 41.70 & 53.9 & 4.4 \\
\hline 6 & 10.51 & 7.2 & 82.3 & 44.40 & 50.6 & 5.0 \\
\hline 7. & 16.41 & 10.5 & 73.1 & 45.77 & 49.0 & 5.2 \\
\hline 8 & 21.68 & 13.8 & 64.5 & 46.46 & 48.1 & 5.4 \\
\hline 9 & 24.42 & 16.0 & 59.6 & 46.86 & 47.4 & 5.7 \\
\hline 10 & $28: 43$ & 19.0 & 52.6 & 47.03 & 47.0 & 6.0 \\
\hline 11 & 33.76 & 24,0 & 42.2 & 46.32 & 40.2 & 13.5 \\
\hline 12 & 41.0 (estm) & 2) 32.8 & 26.2 & $41.0($ estm $)$ & 32.8 & 26.2 \\
\hline
\end{tabular}

* Measured data ** From Fig. 1. *** Balanced values 


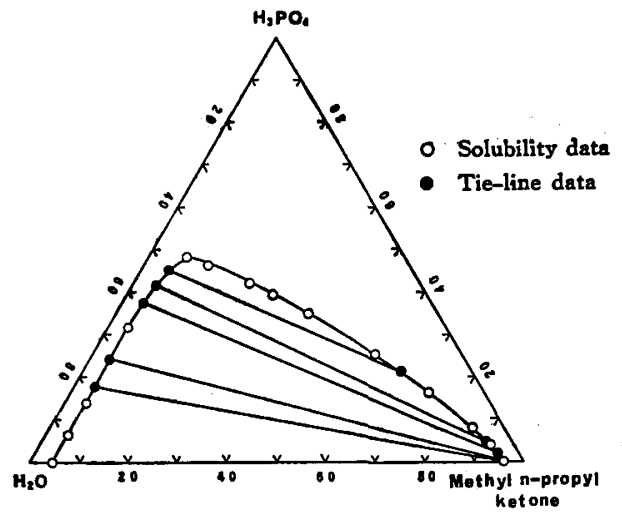

Fig. 1 Solubility curve and tie-lines for phosphoric acid-water-methyl $n$-propyl ketone $\left(25^{\circ} \mathrm{C}\right)$

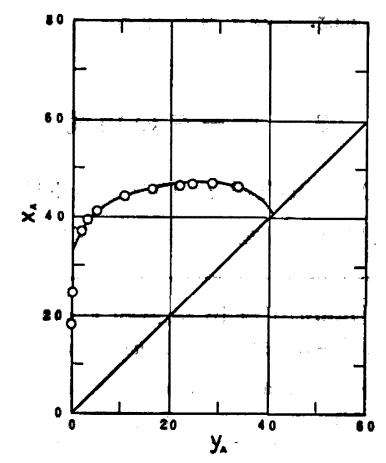

Fig. 2 Distribution curve for phosphoric acid-watermethyl n-propyl ketone

Run No. 8, 9, 10, 11 のよらにブレイトポイントに近 いところでは,

$$
\log y_{4}:\left(x_{4}-y_{4}\right) / y_{4}
$$

のプロット2つが Fig.4のように良好な直線となる。こ の相関值線を外插してプレイトポイントを推定すると，

$$
z_{\Delta}=41.0
$$

といら值を得る。

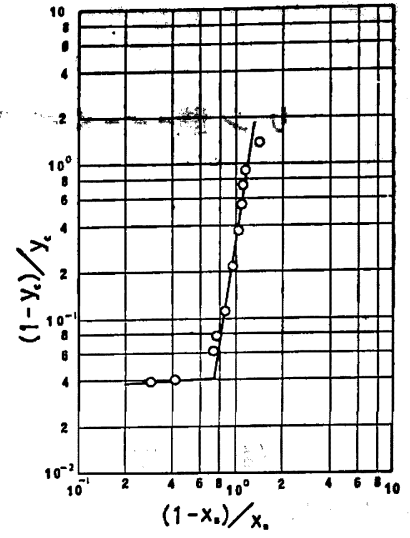

Fig. 3 Othmer-Tobias plot of tie-line data for phosphoric acid-water-methyl $n$-propyl ketone

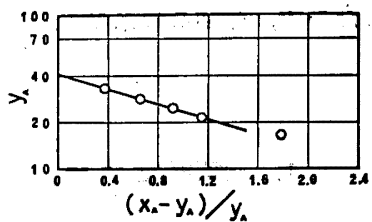

Fig. 4 Correlation for the high concentration region by Iguchi's plots

\section{結 豆}

メチル クープロピルケトンーリン酸ー水系の相平衡を 25 드測り，相互溶解度曲線と対応線データを得た。フ レイトポイントを井ロのブロット2)から推定した。

この系は, 水相内のリン酸の濃度と有機相内のリン酸 漠度の比が1より大きく，対応線の傾きは Fig. 1 のよ らな表し方では右さがりとなる。その傾斜はブレイトが イント近くでは，互いにほぼ平行となる。そして水相内 のリン酸濃度が約 47〜37 wt\% と滅るにつれて, 有機相 内のリン酸の濃度が大きくかわることが確がめらた。

\section{Nomenclature}

$x=$ wt $\%$ of component in water-rich layer

$y=$ wt $\%$ of component in organic solvent-rich layer

$z \quad=$ wt $\%$ of component at plait point

$<$ Subscripts $>$
$\Delta \quad=$ phosphoric acid

B $=$ water

c $\quad=$ methyl $n$-propyl ketone

\section{Literature cited}

1) Hirata, M. and T. Shirotsuka: "Chashutsu Kogaku", Nikkankogyo-shinbun-sha, p. 389 (1964)

2) Iguchi, A.: Kagaku Kogaku, 34, 41 (1970)

3) "Kagakukogaku-benran", 3 rd ed, Maruzen, p. 712 (1968)

4) Kotera, A.: "Butsurikagaku-jikkenho", Asakura-shoten, p. 147 (1963)

5) Moroto, S. and A. Watanabe: Kagaku Kögaku, 35, 370 (1971)
6) Moroto, S. and A. Watanabe: Kagaku Kogaku, 38, 323 (1972)

7) Moroto, S. and A. Watanabe: Nippon Kagaku Kaishi, 1972, 2317

8) JIS, K 9005, Nippon-kikaku-kyokai (1961)

9) Othmer, D.F. and P.E. Tobias: Ind. Eng. Chem, 34, 693 (1942) 